\title{
Empirical Study on Chinese Brand Concept in the Mind of the Foreigner Based on BCM Technology
}

\author{
Jing $\mathrm{Li}^{1, \mathrm{a}}$, Hai Hao${ }^{1}$, Meng Huang ${ }^{2, \mathrm{~b}}$
}

1.2 Economics and Management School of Tian Jin University of Technology and Education, China

alijingjing@live.com, b178860837@qq.com

*Jing Li

Key words: BCM technology; Chinese brand; oversea market

\begin{abstract}
Nowadays brand internationalization becomes an important topic discussed by manager and scholar. In the business environment of product homogeneity, it becomes more and more important to consider brand strategy in the perspective of the consumer. This paper introduces the BCM(Brand Concept Map) technology , and then takes Africa market as an empirical example to draw a brand picture in the mind of foreigner consumer, finally give the suggestion to Chinese brand internationalization.
\end{abstract}

\section{Introduction}

With the acceleration of global economic integration and the intensification of international marketing competition, brand internationalization has become a hot topic for both enterprises and scholars. In the United States, "Business Week" valued the world's top 200 brands in the absence of Chinese brands. Chinese enterprises have been in the lowest end of industrial value chain due to the lack of Chinese own brands, for example, a pair of Nike shoes is usually priced at around 600 700 yuan, while the price paid to Chinese manufacturers may be less than 100 yuan. Previous researches related Chinese brand internationalization mainly focused on analyzing the effect of the preferences of the source countries on brand image. The research to explore how the foreigners view Chinese brand and the mechanism it happens is still relatively rare. t. This study applied BCM (Brand Concept Map) technology to draw the structure of Chinese brand associations of African consumers, and explored the Chinese brand image in the eyes of foreigner consumers in developing countries, finally put forward suggestions for the development of Chinese brand globalization. The study of these problems is of great significance to the theoretical research and practice of the Chinese brand globalization market.

\section{The Analysis of the BCM Technology}

According to the associative network memory model ${ }^{[2][3][4]}$ of cognitive psychology, the brand in the form of "a name, term, marker, symbol or combination of them" exists in the brain as a band node. Through direct or indirect contact with the brand and their consumption experience, consumers generate cognitive information about organizations, products, or services related to cognitive, affective experience, experience of use, which are directly or indirectly connected with the brand nodes in the memory network, and form the brand association. Brand association can be "in memory of a brand associated with anything", and the combination of these brand associations constitute a consumer's perception of the brand attitude, that is, brand image. Based on the brand awareness and brand image, the consumer makes a positive or negative reaction to the marketing behavior of the enterprise, which constitutes Brand equity. Because of the implicit and metaphorical characteristics of brand association, it is difficult to explore the brand image and the mechanism of the view forming. In the research of requiring consumer brand association and brand attitude, the typical methods are ZEMT ${ }^{[5]}$, $\mathrm{NA}^{[6]}$ and $\mathrm{BCM}^{[7]}$. BCM (Brand Concept Map) technology is more advantageous than the other two methods in the feasibility and the reliability, which can show a picture of consumers how to consider the brand as shown in finger1. 
BCM can help managers understand the key content of brand association in the consumer's mind, and realize how the associations connect together and find the driving node that forms the core brand associations, and then analysis the formation causes and evolution path of the brand image.

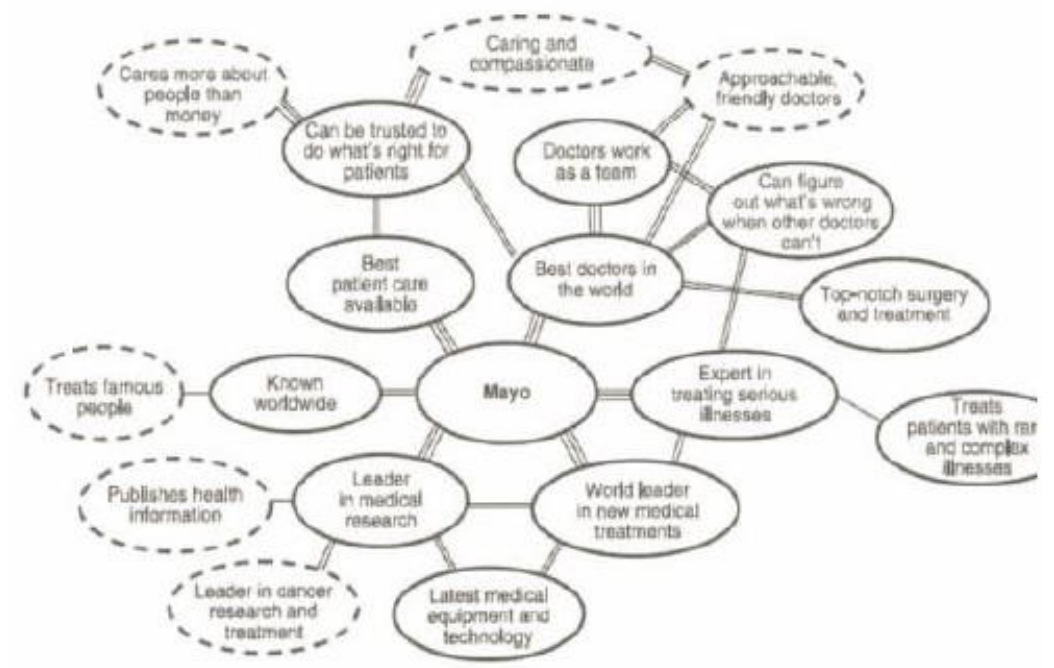

Figure 1. The structure of brand association is draw by the method of BCM.

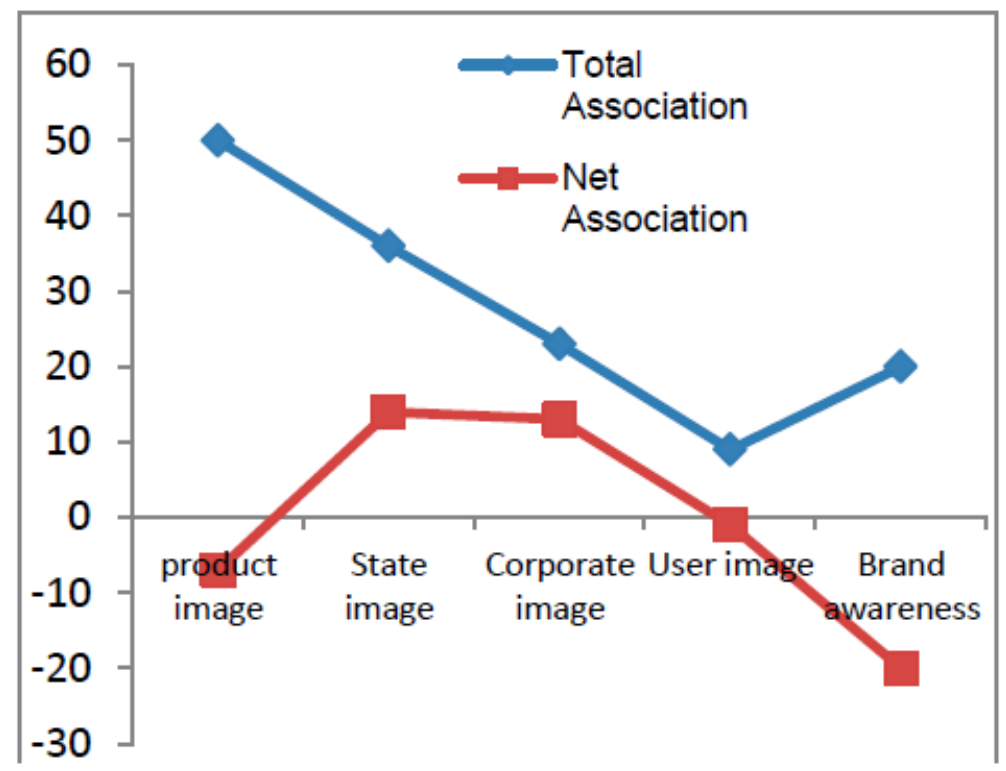

Figure 2. Analysis of the structure of the brand associations.

\section{Empirical Analysis of Chinese Brand Concept in the Mind of the Foreigners}

In 2011 imports from China accounted for $16.8 \%$ of total imports of goods in Africa according to the report from Standard Bank of South Africa. With the rapid economic development in Africa, Africa market is increasingly showing a trend of diversification and more pursuing the taste and luxury according to the report of McKinsey .In the face of a huge and potential market in Africa, what Chinese brand image in the minds of consumers in Africa is, and how the mechanism of the brand concept organizes are deserved to explorer more. This study randomly selected from 15 African college students for empirical study, draw out the psychological concept map of Chinese brand in the mind of African consumers by using BCM technology, and further analysis of its mechanism.

3.1 Brand Content Acquisition. In elicitation stage, the interview revolving around the topic of "what can you think of when China brand is mentioned", guided the respondents by using Kelly Grind and Weak ladding study, selected 30 brand association whose frequency of being mentioned was relatively high (more than 50\%) through the summary and similar merger, which includes 7 
factors of product image, 10 factors of the corporate image, 2 factors of the User image, 9 factors of the national image, and 2 factors of brand awareness. The content summary is shown in table 1:

Table 1: summary of brand associations

\begin{tabular}{|c|c|c|}
\hline $\begin{array}{c}\text { elemen } \\
t\end{array}$ & $\begin{array}{l}\text { Content summary (the number is the } \\
\text { count of mentions) }\end{array}$ & Association type and amount \\
\hline $\begin{array}{l}\text { product } \\
\text { image }\end{array}$ & $\begin{array}{c}\text { low price(6),Poor quality(7), } \\
\text { fake(8),Lack of innovation(5),Poor } \\
\text { after-sales service(9),A variety of } \\
\text { products(5),Good design (8),Creative } \\
\text { ability (2) }\end{array}$ & $\begin{array}{l}\text { Total Association(50); } \\
\text { Net Association(-7); } \\
\text { Positive evaluation }(21) ; \\
\text { Negative evaluation }(29)\end{array}$ \\
\hline $\begin{array}{l}\text { nationa } \\
1 \text { image }\end{array}$ & $\begin{array}{l}\text { Rapid economic development(5), The } \\
\text { serious pollution of the } \\
\text { environment(5),Good living conditions in } \\
\text { China(2),Social stability in China(2), The } \\
\text { degree of democratization is not } \\
\text { high(2), Chinese life under great } \\
\text { pressure(4),Chinese are very } \\
\text { friendly(5),Close } \\
\text { China-Africa relations(5),Strong science } \\
\text { and technology and R \& D of China(3) }\end{array}$ & $\begin{array}{l}\text { Total Association }(36) ; \\
\text { Net Association }(14) ; \\
\text { Positive evaluation }(25) ; \\
\text { Negative evaluation }(11)\end{array}$ \\
\hline $\begin{array}{l}\text { Corpor } \\
\text { ate } \\
\text { image }\end{array}$ & $\begin{array}{l}\text { Lack of social responsibility(3),No } \\
\text { business ethics, made no contribution to } \\
\text { the local (2),Large enterprise } \\
\text { scale(4),Diligent employee(5),made } \\
\text { contribution to the local(5),powerful } \\
\text { Company strength(2),Have a strong sense } \\
\text { of social responsibility (2) }\end{array}$ & $\begin{array}{l}\text { Total Association(23); } \\
\text { Net Association( } 13) ; \\
\text { Positive evaluation(18); } \\
\text { Negative evaluation }(5)\end{array}$ \\
\hline $\begin{array}{l}\text { User } \\
\text { image }\end{array}$ & $\begin{array}{l}\text { Users are low income, low cultural class } \\
\text { (5),young people (4) }\end{array}$ & $\begin{array}{l}\text { Total Association(9); } \\
\text { Net Association(-1); } \\
\text { Positive evaluation (4); } \\
\text { Negative evaluation (5) }\end{array}$ \\
\hline $\begin{array}{c}\text { Brand } \\
\text { awaren } \\
\text { ess } \\
\end{array}$ & $\begin{array}{l}\text { Lack of independent brand (9), Less } \\
\text { publicity (5),Low brand awareness (6) }\end{array}$ & $\begin{array}{l}\text { Total Association(20); } \\
\text { Net Association }(20) ; \\
\text { Negative evaluation }(20)\end{array}$ \\
\hline
\end{tabular}

As shown in Figure 2, in the context of the African consumer's brand association about Chinese brand, the total largest number of association is the product image, followed by the national image and corporate image, finally the image of the user and brand awareness. The product image and brand awareness are negative association, mainly manifested as poor quality, lack of innovation (piracy and counterfeiting), low product safety, the lack of independent brands, Less publicity, Low brand awareness; Net Association of Chinese national image and Corporate image is positive.

3.2 Research on Structure Analysis of Brand Association. In the personal mapping stage, the first to introduce the method of brand concept map for respondents, and to provide Figure 3 as a reference pattern; the next respondents are asked to select appropriate association to make a brand network map described brand from the elicitation stage which have selected a set of brand associations in the form of cards or you can write brand association that not existed before on new cards adding to the drawing map; Respondents connected to each of the items using one, two, and three lines to indicate the strength of associations (the three-line shows an extraordinary strong connection and a single line represents a weak connection), and eventually form a personal brand in the map. On the basis of personal drawing, the individual maps drawing by each individual are integrated, and a consensus map is created. As shown in Figure4, we can see the overall situation of China's brand image in the minds of African consumers and the path of formation. 


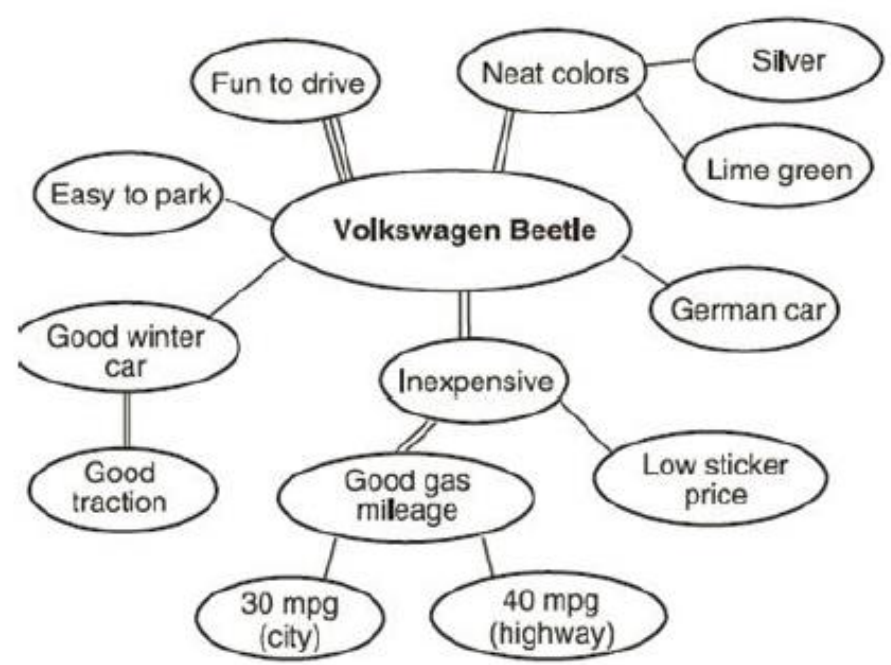

Figure 3: BCM reference template for subjects

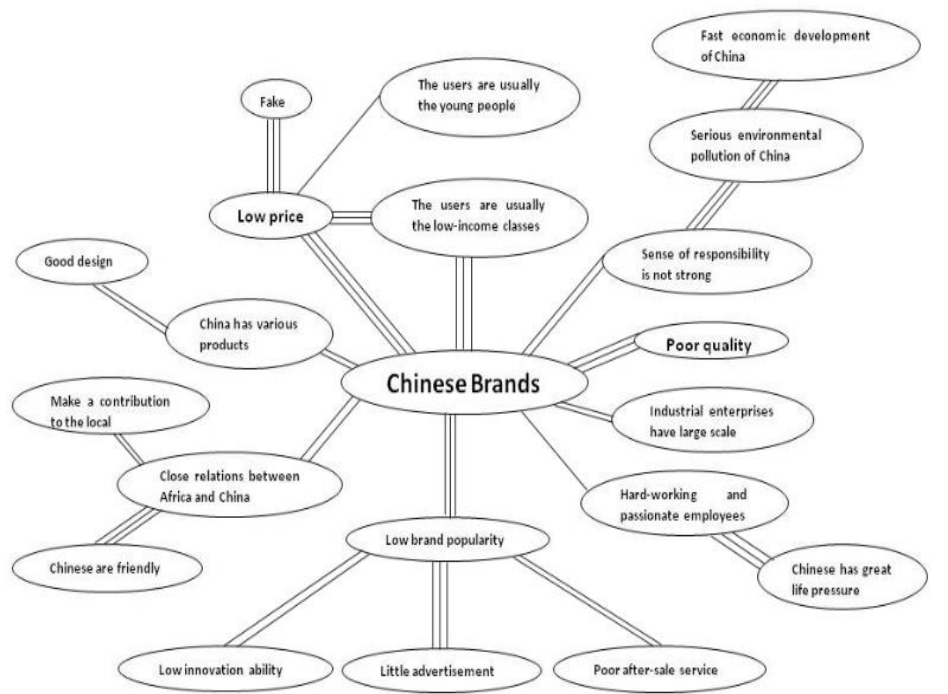

Figure 4: A summary of the brand concept map

Through the brand concept map of BCM technology to draw, we can intuitively understand the view of the subjects about Chinese brand and reasons for attitude formation. Chinese overall brand image still stays in the low-quality, product design fashion, and rich variety as well as low-end brand that the customers' group level is not high. Chinese brand consciousness, the popularity of Chinese brand in the African market is not high, a lot of consumers' awareness of the Chinese brand mainly rely on the impression of national image, and then infer the quality of the products .The attitude towards to the impression of China is better than Chinese products ,and said that if the quality of the product is good, they will take Chinese products as the choice of purchasing, which is consistent with the research finding that the origin country affected the evaluation of product. At the same time when referring to China brand, most consumers will associate with the image of Chinese corporate in Africa, relatively strong association is "Chinese industrial enterprises have larger scale in Africa", "employees of enterprise are hard-working", "low innovation ability of enterprises".

\section{Conclusion and Thinking}

According to the research finding by means of BCM technology reflects the development status of Chinese brand in African market, the overall awareness of Chinese brand is low, and the most intuitive brand image is cheap, low quality. Foreigner consumers' impression of unfamiliar Chinese brands will be affected by China's national image, corporate image and brand image. The establishment of Chinese brand assets in overseas markets consider firstly how to expand brand 
awareness by means of marketing strategy, so that more overseas consumers are familiar with the brand to form the brand awareness, afterward, create brand reputation. The building of brand reputation is involved to both improve the perceived quality of Chinese brand and brilliant national image worldwide. At the same time, Chinese enterprises should establish an excellent and recognized business reputation around the world involving contribution to local economic, trustiness and reliability.

\section{Acknowledgement}

This research was financially supported by Research Funds for the African Union Research Center of Tianjin University of Technology and Education (Grant NO.FMY13-04) and Research Funds for Tianjin University of Technology and Education (Grant NO. SKY15-03, SK13-12)

\section{Reference}

[1] Xiaozhou He. Foreign consumers' perception research to the "made of china" [D]. Chongqing University,2009

[2] Anderson, J. R. The Architecture of Cognition.Cambridge, MA: Harvard University Press,1983

[3] Krishnan, H. S.Characteristics of memory associations: a consumer-based brand equity perspective [J]. International Journal of Research in Marketing, 1996(13): 389-405.

[4] Janiszewski.C.,\& van Osselaer, S. M. J. A connectionist model of brand-quality associations [J].Journal of Marketing Research, 2000(37):331-350.

[5] Coulter, R.H.,\&Zaltman,G . Using the Zaltman Metaphor Elicitation Technique to understand brand images. advances in consumer Research, 1995(21):501-507.

[6] Henderson, G. R., Iacobucci, D., \& Calder, B. J. Using network analysis to understand brands [J]. Advances in Consumer Research, 2002(29): 397-405.

[7] John, D. R., Loken, B., Kim, K., \& Monga, A. B. Brand concept maps: a methodology for identifying brand association networks [J]. Journal of Marketing Research,2006(43):549-563. 